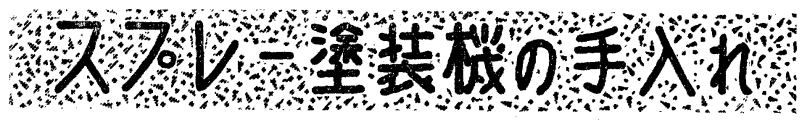

ースプレーガン・2

岩田塗装機工業(株) 福永宣昭

\section{8. スプレーガンの手スレ}

スプレーガンの手入レについては，日常の 手入レと簡便な故障対策について記すことと 与े。

\section{8-1. 使用直後の手入レ}

\section{一先端部の塗料固着を防止一}

(1) 洗浄液（ガソリンまたはシンナー）を 塗料供給容器（重力式はカップ, 吸上式は コンテナー）に入れ，スプレーして㙦料通 路を洗 5 .

(2) 空気キャップ(コマともいう)などの ガン先端部分をブラシでよく洗い落す．ス プレーガン付属のブラシを使用するか，あ るいは比較的柔らかいものを使用すべきで ある。

(3) 空気キャップをはずし，塗料ノズルを ブラシで洗浄する. 塗料ノズル先端の塗料 固着を防ぐためである。

(4) 空気キャップを取り付ける.

(1)〜(4)までの順序に従いこれを行なえばよ いが，先端部分はガンの生命であるから洗浄 液は新らしいものを使うべきである。

\section{8-2. 每日の手スレ}

\section{一ネジ部・テーパー部の}

\section{注油も忘れずに一}

(1) 前述の使用直後の手入レを順序ど括り 行な 5 .

(2) ガンの外観に付着した慗料をブラシか 布で洗浄し，必ず布でふきとる。

(3) 塗料ノズルのテーパー部に油をさし, 空気キャップを取り付㺭る.

(4) 先端部分・調整部分・本体のネジ部あ るいはテーパー部に油をつける。

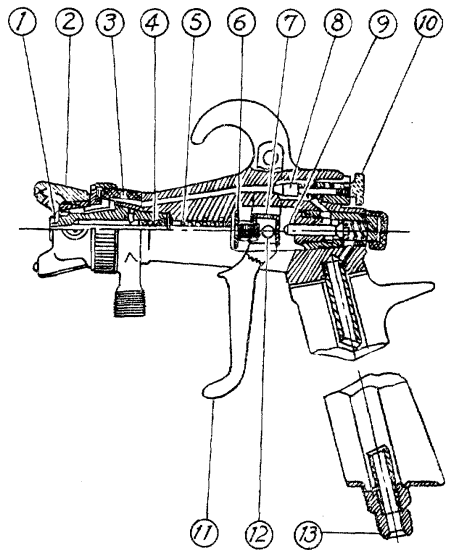

\begin{tabular}{|c|c|c|c|}
\hline 番号| & 部 品 名 & 番号 & 品 \\
\hline 1 & ノズル & 8 & 空気止メハルプ \\
\hline 2 & 空気キャップ(コマ) & 9 & パルブ心棒 \\
\hline 3 & 容器取付ジョイント & 10 & 空気調整ネジ \\
\hline 4 & 石綿パッキング & 11 & 引 金 \\
\hline 5 & 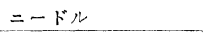 & 12 & 回転ビス \\
\hline 6 & 塗料調整ネジ & 13 & ジョイント \\
\hline 7 & $\exists-\eta$ & & \\
\hline
\end{tabular}

第1図 スプレーガン構造図

油質は一般の機械油か，低粘度グリスを使 用するとよい，使用量は油膜を作る程度でよ く，それ以上つけても浪費である.

一般に(3)での手入レを行なっても(4)はあ まり行なおない作業員が多いようであるが， 機械摩擦の生ずる所には必ず潤滑油をつける のを習慣とすべきである。

\section{8-3. 1 週間ごとの手入レ}

\section{一各作業部分の点検と締増シー}

(1) 塗料ノズルをはずし，ニードル弁バッ キンの締增シを行なう。 
第1表 スプレーガン故障の原因と対策

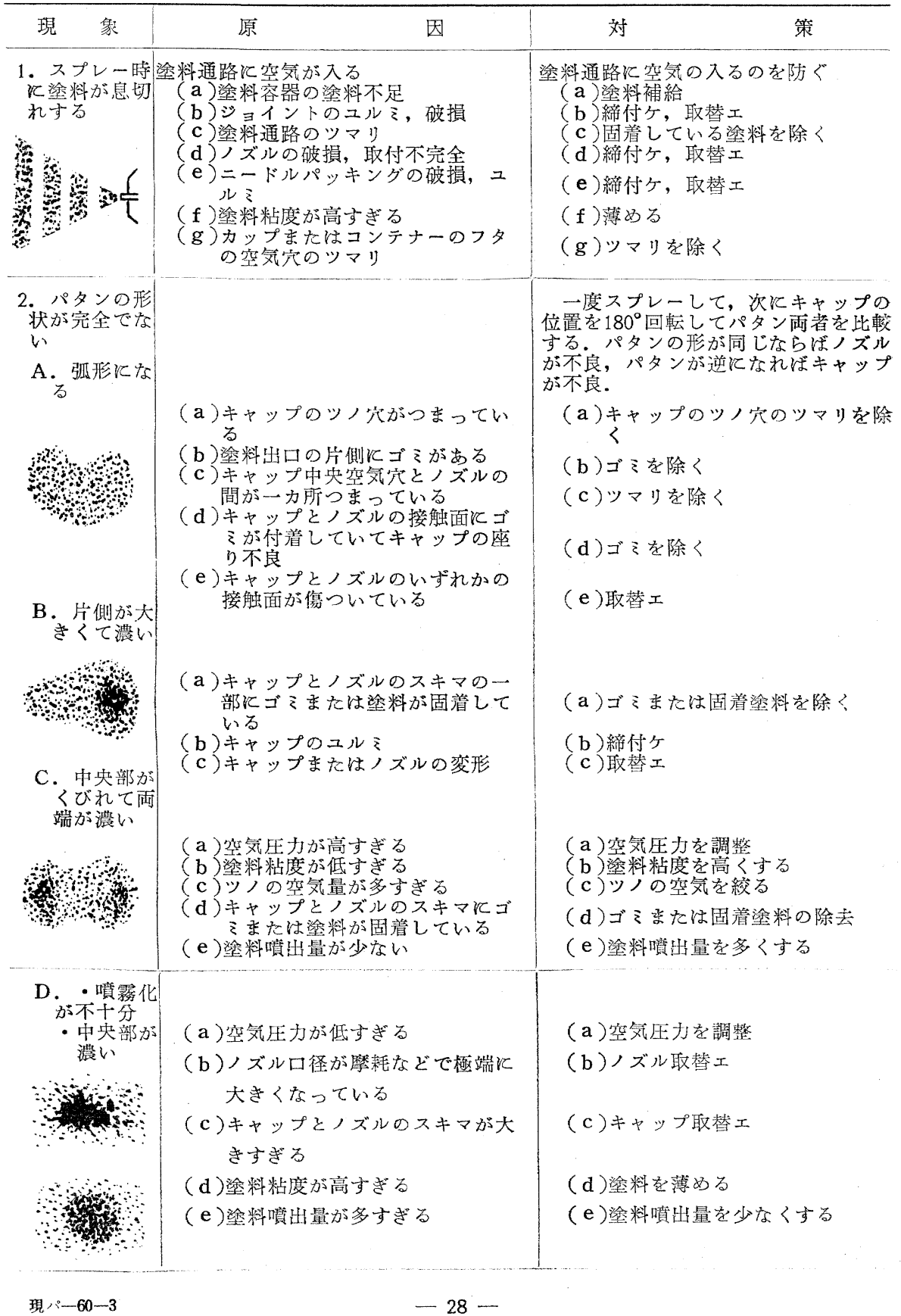




\begin{tabular}{|c|c|c|}
\hline 現 象 & 原 & 対 \\
\hline $\begin{array}{l}\text { 3. ニードルパ } \\
\text { 間か } \\
\text { ら塗料が漏る }\end{array}$ & $\mid \begin{array}{l}\text { パッキング不良 } \\
\text { パッキングのユル 破損 }\end{array}$ & 締付ケ, 取替エ \\
\hline $\begin{array}{l}\text { 4. ガンの先端 } \\
\text { から空気が漏 } \\
\text { る }\end{array}$ & 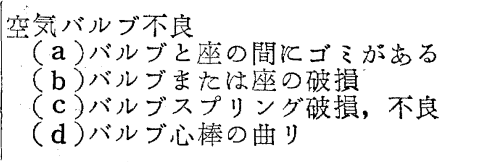 & 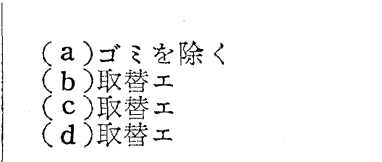 \\
\hline $\begin{array}{l}\text { 5. ガンの先端 } \\
\text { から塗料が漏 } \\
\text { る }\end{array}$ & 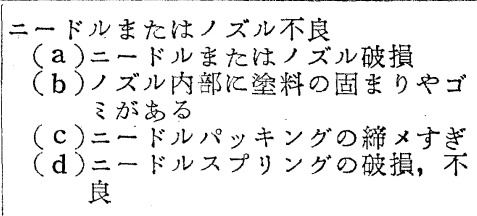 & $\begin{array}{l}\text { (a )取替エ } \\
\text { (b )固着塗料, ゴミを除く } \\
\text { (c) ゆるめる } \\
\text { (d) 取替エ }\end{array}$ \\
\hline
\end{tabular}

(2) 空気バルブをはずし，バルブ部分を洗 浄し注油する。

(3) 各作動部分を点検, 締増シを行な5.

息切レの注とえどの原因がニードル弁パッ キングで，作業量にもよるが毎週行なえば問 題は生じない，ただし，毎週の手入レより， 後記する毎月六力月後の手入レがたいへ几重 要である.そして，この手入レを作業者が行 なうかむるいは専門者に移管させるか性態 の規模により変ってくるが，専門者に行なわ せるほうが道具, 構造などの知識からみて良 策である。

\section{8-4. 每月の手入レ}

\section{一先端部分の分解点検一}

先端部分を分解し, 各部品を点検して塗料
の固着をよく取払い，損傷部分の有無につい て前述スプレーガンの性能の項で述べたよ5 な方法をとって調查することが必要である.

\section{8-5. 6 カ月ごとの手スレ}

\section{一精密な分解点検と部品の交換一}

先端部分, 調整部分を分解, 点検し, 注油, 組立を行なう。この場合は部品の交換も行な って性能の良否を調べ，その变化状況を記帳 する. スプレーガンも一種の精密機械である から，このくらいの調查は有効な管理の手法 と考えるべきである。

\section{8-6. 故障対策}

スプレーガンの簡便な故障対策を第 1 表の 一覧にをとめる.

\section{作 業 研 究}

(32ページからつづく)

を表わす大きい円一つで，左手がいかにも作 業をしていないということがはっきりわか る、これに引きかえ, 第35図は, 左右両手が 闰時に対照の方向に動き，まったく運動経済
の原則にかなう作業をしている。すなわら新 しい方法によれば，古い方法で 1 個のでき上 り品を組み立てる時間にほんの少しの時間を プラスするだけで，2 個できるので，1個当 りの生産費がずっと安くなる. 